\title{
İslam Ekonomisi Perspektifiyle Bir Büyüme Modeli Çerçevesinde Üretim ve Sosyal Refah Fonksiyonu
}

\section{Ahmet $\mathrm{EFE}^{10}$}

\section{Öz}

Bu çalışmamızda İslami bakış açısıyla İslam ekonomisinin büyüme, üretim ve sosyal refah fonksiyonu ile ilgili temelleri incelenmektedir. İddiamız, modern iktisat öğretileriyle analiz edilebilecek şekilde İslam ekonomisinin büyüme, üretim ve sosyal refah fonksiyonunun oluşturulabileceğidir. Ekonomi ve İslam dini çerçevesinde yapılan analizlerde çağdaş ve orijinal bir yaklaşımla kapitalist sisteme nazaran Kuran düzeninin ekonomik hükümleri tesis etmedeki farklııkları özet olarak ortaya konulmaktadır. Buna göre, dünya hayatını merkeze alarak diğer her şeyi dünyadaki maddi kazanımlar açısından araçsallaştıran batı yaklaşımına nazaran dünyayı, geçici dünya hayatını ve bütün gereklerini ebedi olan ahiret hayatını kazanmak için bir araç olarak görerek her iki hayatı da değerleri kadar önem veren İslami yaklaşımın İslam ekonomisinin büyüme, üretim ve sosyal refah açısından iyileştirici fonksiyonu ortaya konulmaktadır. Üretim; insana ve doğaya zarar vermeyecek şekilde intiyaca göre, ekonomik büyüme; çevreyi ve gelir dağııımını dikkate alarak sürdürülebilir bir şekilde ve sosyal refah da; sadece güçlü ve zenginlere değil toplumun tüm kesimlerinin bir birisini gözettiği ve gönüllü paylaştığı bir şekilde farklıı̆ını ortaya koymaktadır.

Anahtar kelimeler: İslam ekonomisi, büyüme modeli, üretim, sosyal refah

\section{ABSTRACT}

\section{Production, Social Welfare, and Growth: An Islamic Economics} Perspective

Our argument is that since the Islamic religion is valid and pervasive, its economic results should be more congruent, logical, and beneficial in providing human happiness and easing the burden of worldly life. Whereas the Western style subjugates everything that can serve material progress and capital accumulation as a means of production or productive relations, Islamic philosophy takes the world only as a temporary place but worthwhile to the extent
'Dr., CISA, CRISC, PMP, Ankara Development Agency Internal Auditor, Ankara, Turkey

Corresponding author/Sorumlu yazar: Ahmet EFE,

Ankara Development Agency Internal Auditor, Ankara, Turkey

Phone/Telefon: +90-312-3100-300/172

E-mail/E-posta: aefe@ankaraka.org.tr

Date of receipt/Geliş tarihi: 29.12.2016 Date of acceptance/Kabul tarihi: 28.09.2017

Citation/Atıf: Efe, A. (2017). İslam Ekonomisi perspektifiyle bir büyüme modeli çerçevesinde üretim ve sosyal refah fonksiyonu. Istanbul Journal of Economics, 67, 31-58. https://doi.org/10.26650/ISTJECON372362 
that it preserves life; therein, production is a process that excludes whatever is harmful to humanity and nature, economic growth takes environmental issues and revenue distribution into account and social welfare is not just for wealthy people it is distributed by sincerity to all people in society.

Keywords: Islamic Economics, growth model, production, social welfare

\section{EXTENDED ABSTRACT}

Production and social welfare are relative and interdependent functions in macroeconomics. While the productive capacity of a nation is measured by GDP and its derivatives, social welfare requires the consideration of other determinants such as purchasing power, GDP per capita, minimum wages, unemployment rate, and social security payments. The more GDP per person, the higher the government revenues and social security is an important ceteris paribus assumption in open democracies. For wealthy nations, social welfare expenditure has become one of the biggest challenges of governments and a bottleneck in financial management. The financial mechanism of interest vis-à-vis the banking system provides a platform of exploitation of labor by capital owners. The social culture of wealthy people that do not care about the wellbeing of the poor has a tremendous negative effect over social welfare.

As a requirement and/or indication of social welfare, the upper and lower classes in human society, that is, the rich and the poor, live at peace when in equilibrium. The basis of that equilibrium is compassion and kindness of the upper classes, and respect and obedience in the lower classes. If the upper classes do not oppress and the lower classes obey laws and rules, social welfare will be sustainable. Now, the individualistic attitude of mind that "So long as I'm full, what is it to me if others die of hunger" lacks compassion for the poor. Furthermore, another deleterious attitude of mind, "You work so that I can eat," provides a basis of exploitation by upper classes. The first ominous phrase has incited the upper classes to practice oppression, immorality, and mercilessness; while the second has driven the lower classes to hatred and envy and has negated man's tranquility for several centuries. So too this century, the struggle between capital and labor has been the cause of momentous events in Europe well-known by all. Thus, 
together with all its societies for good works, all its establishments for the teaching of ethics, all its severe discipline and regulations, it could not reconcile these two classes of mankind, nor could it heal the two fearsome wounds in human life. The Qur'an, however, delegitimizes the first phrase with its injunction to pay zakat. While it uproots the second phrase with its prohibition on usury and interest. Indeed, the Qur'anic verse stands at the door of the world and declares usury and interest to be forbidden.

In capitalist societies people are exposed to negligence in their social and family relationships and excessiveness in both personal consumption and concerns for superficialities. Economic and social relations in capitalist societies are based on a materialistic point of view, resulting in an unequal wealth distribution and inefficient, wasteful use of economic and social capital. Islam stands in the abovemiddle course between capitalist and socialist systems. Islam advocates a wealth distribution mechanism with a view to realizing a society in which there will be accumulation of wealth but not in monopolistic and oligopolistic terms. Usury, hoarding, and profiteering can only be the act of marginal wrongdoers. A society in which the impoverished and wealthy help the poor with their zakat with the proletariat willing to add value to production processes is not far away according to the Islamic point of view. The socio-economic role of Zakat in Islamic social welfare is proven for its effectiveness in combating chronic poverty, hunger, and social hindrances in society. It is understood that Zakat provides a sustainable mechanism in the economy and social balance of societies, to provide transfer of income from the rich to the poor serving as a bridge between the bottom and the top. Once aptly assessed, efficiently collected, and fairly distributed, it plays the role of solving dangerous socio-economic problems such as poverty, class tensions, unemployment, insurgency, indebtedness, and unfair income distributions.

Our argument is that since the Islamic religion is valid and pervasive, its economic assumptions, requisites, and results should be more congruent, logical, and beneficial in providing human happiness and easing the burden of worldly life. Whereas the Western style subjugates everything that can serve material 
progress and capital accumulation as the means of production or productive relations. Islamic philosophy takes the worldly life only as a temporary place but worthwhile to the extent that it preserves life; therein, production is a process that excludes whatever is harmful to humanity and nature, economic growth takes environmental issues and revenue distribution into account and social welfare is not simply synonymous with the capital accumulation of wealthy people, but rather embraces distribution to all people in society.

\section{Giriş}

Bir sosyal bilim olarak ekonomi, insanların ve toplumların sahip oldukları sınırlı kaynaklarıyla onların sürekli gelişen sınırsız ihtiyaçlarını karşılama bilimi veya ekonomik tercihleri analiz ederek belirli teori ve kavramlar ışığında değerlendirme olarak tanımlanmaktadır. İnsan ihtiyaçları ve tercihleri kuşkusuz insanın etkisi altında bulunduğu felsefi akımlara göre değişkenlik gösterebilmekte ve ekonomik tercihlerin piyasaya yansıtılmasında davranışların arkasında bilinç düzeyi, algılar, inanışlar ve kültürel değerler de etkili olduğundan salt açıdan ekonomik fayda veya objektif kullanım/değişim değerleri ile açıklayabilmek olanaklı değildir. Çünkü iktisat pozitif olduğu kadar normatif ve objektif olduğu kadar da sübjektif parametrelerin dikkate alınarak değerlendirildiği bir sosyal bilim dalıdır. Bu nedenle de ekonominin felsefik, psikolojik ve sosyolojik temelleri, ekonomik adamın tercihleri, algısı, değerleri ve davranışlarını tetikleyen bilişsel etkenler çerçevesinde değerlendirebilmek önem arz etmektedir. İslam ekonomisi ile ilgili çalışmalarda ise bunlara ek olarak tevhid, şeriat, iman, amel ve ihlas gibi temel gibi temel esasların irdelenmesi gerekmektedir.

İslam ekonomisiyle ilgili bilimsel disiplin alanında şer'i hukuk yaklaşımları ile birlikte finansman metotları daha ağır bastığından modern iktisat dışında nasıl bir analitik yaklaşım gösterilmesi gerektiği de henüz tam olarak netleşebilmiş değildir. Pür İslami yaklaşımda modern iktisadi kuramlara benzer analizler yapılmadan ve maddi sermaye birikimleri dikkate alınmadan sadece normatif ve sübjektif analizler ve kabullere dayalı önermeler eksik kalmaktadır. İnsanın ekonomik birikimleri ve toplumsal refah yanında insan huzuru, saadeti ve lezzeti hem dünya 
hem de ahiret kazançları açısından ele alınarak her an ölümle yüz yüze bulunabilen insanın en önemli sorununun yok olmaktan ve cehennemden kurtulmak olduğunun altı çizilerek insanın elindeki ömür sermayesinin kıt bir kaynak olarak nihayetsiz ihtiyaç içerisinde bulunduğu yokluktan kurtulmak ve saadetli ebedi yaşama kavuşturacak şekilde kullanılması gerekliliği üzerinde değerlendirmeler yapılabilmelidir. Dolayısıyla, İslam ekonomisinin esası olarak insanın dünya hayatından ziyade ahiret hayatının kazanmasına odaklanırken İslam'ın mucizevi bir yönü olarak dünya hayatının da daha saadetli, mutlu ve lezzetli geçirilebildiği ortaya konulabilmelidir. Yani dünyevi maddecilik veya ekonomik determinizmin hâkim olduğu kapitalizm ve komünizmden arınarak, sermaye birikimi, güç ve maddi olanaklar üzerindeki yarışa kapılmadan dünyevi aşırılıklardan korunmuş bir şekilde orta yol tercih edilmesi mümkündür.

Modern iktisat teorisinin sadece dünya hayatıyla ilgili sınırsız ihtiyaçların sınırlı kaynaklarla karşılanabilmesi noktasında analizler yaparken, İslam ekonomisi dünya hayatını değil aynı zamanda ahiret hayatını da dikkate alırken ahiret hayatını dünya hayatına öncülleyen ve dünya hayatını da ahiretin bir tarlası bir mezrası gibi eldeki kaynaklardan birisi olarak değerlendirir. Buradaki temel yaklaşım da bu noktada her gün verilmiş olan yirmi dört saatlik ömür de bir kıt sermaye olarak ele alınmakta ancak bu sermaye ile ebedi bir hayatı dünyalar kadar bağlar ve bahçeler kazanma imkânı sunan bir fırsat olarak ele alınmaktadır. Bu yaklaşımda elbette insanın etkisinde bulunduğu yaklaşım ve düşünce alt yapısının da dikkate alınması gerekmektedir. Bu çalışmamızda İslam ekonomisiyle ilgili analizlerde toplam talep ve toplam arz ile ilgili değerlendirmelere girilmeden sosyal refah alanında nasıl bir perspektif gerektiği araştırılmaktadır. Bilimsel disiplin çerçevesinde yapılan analizlerde normatif ve sübjektif olarak algılanabilen pek çok parametrenin belirli bir metot ile denklem içerisine dahil edilmesinin araştırması yapılmaktadır.

\section{Metodoloji}

Araştırmamızda betimleyici ve ilişki arayıcı mantıksal analiz metotları kullanılmaktadır. Ebsco veri tabanında yabancı literatür taraması yapılmıştır. Buna göre "Islamic economics" olarak yapılan aramada 189 adet makale, "growth model" 
olarak yapilan aramada 11,824 adet makale, "production and social welfare" olarak yapılan aramada 2,485 adet makale "çıkmıştır. Dolayısıyla İslam ekonomisi, büyüme modeli ve üretim ve sosyal refah ile ilgili yeterli düzeyde yabancı literatür bulunduğu söylenebilir.

Türkçe literatür araştırması için de "islam ekonomisi" olarak yapılan aramada 10 adet makale, "büyüme modeli" olarak yapılan taramada 111 makale, "üretim ve sosyal refah fonksiyonu" olarak yapılan taramada 42 yayın tespit edilmiştir. Dolayısıyla araşıırma alanında yeterli düzeyde yabancı yayın varken Türkçe literatürde yeterli düzeyde olmadığı görülmektedir. Bu husus da kuşkusuz yaptığımız çalışmanın Türkçe literatüre olan katkısının önemli olduğunu ortaya koymaktadır.

Bu çalışmamızda temel amaç, İslam ekonomisinin ekonomik ve sosyal boyutuna dair detaylı bir çalışma yapmak değildir. Zira bu ancak bir kitap çalışmasına konu edilebilecek düzeyde kapsamlı bir analiz ve değerlendirmeyi gerektirmektedir. Buradaki temel amaç, İslam ekonomisinin temellerinin ortaya konularak bunların modern iktisadın dayandığı üretim ve refah fonksiyonlarıyla analiz edilebildiğini göstermektir.

Bu amaçla öncelikle, İslam ekonomisiyle ilgili sorunlar değerlendirilerek araştırma problemi yapılandırılmakta; modern ekonominin temelleri konuyla ilişkisi bağlamında değerlendirilmekte; din kültürü ile ekonomi arasındaki ilişkiler kuramsal ve kavramsal boyutlarıla ele alınmakta; İslam şeriatı ile ekonominin nasıl düzenlendiği üzerinde durulmakta; ekonomik büyüme ve üretim fonksiyonu ile mikro ve makro açıdan sosyal refah fonksiyonunun elde edilmesi analiz edilmeye çalışılmaktadır.

\section{Araştırma Problemi}

Araştırmamızın hareket noktası da İslam toplumlarında daha çok batı felsefesinin ürünü olan sistem, yaklaşım ve politika paketleri ile kurumsal yapılanmalardan çoğunlukla sonuç alınamaması ve İslam ülkelerinin batılı merkez kapitalist ülkelere göre üretici olmaktan çok tüketici ve çevre toplulukları gibi görünmeleridir. 
Bunun yanı sıra, bazı araştırmacıların da ifade ettiği üzere, Müslümanların maddi olarak geri kalmışlıkları ve aralarında birliğin olmamasının aslında onları arzuladıkları caddede ilerlemelerini sağlayabilecek olan Kuran'ın Dünya görüşü yani Kuran felsefesinden uzaklaşmış olmalarıdır (Shittu, 2014, s. 240).

İslam ekonomistlerinin batı felsefesiyle verilen eğitim süreçlerinden geçmesi onların aynı gözlükle bakmalarına neden olduğundan dolayı temel sorun aslında eğitim sisteminde yatmaktadır. Çoğu Müslüman çocuklar günümüzde batı tarzı materyalist felsefeyle yoğrulmuş olarak seküler anlayışla eğitilmektedir. Batı tarzı bilginin asimilasyonu için İslam Konferansı Örgütü tarafından İslamabat ile Malezya da İslam Üniversiteleri kurulmuştur. Amaçları ise batı bilgisi ile İslami bilgiyi enterge etmektir (Zaman, 2012, s. 144).

İslam ekonomisinin bir bilimsel disiplin olarak geliştirilmesinde ciddi krizler olduğunu gösteren kanıtlar mevcuttur. Bunun temel sebebi ise Müslüman ekonomistlerin çoğunun batı ekonomisi felsefesini sorgulamadan kabul etmelerinde yatmaktadır. Bu nedenle metodolojik olarak alt yapıyı oluşturan varsayımlar yanlış olduğundan İslami bakış açısı ve felsefesiyle çatışmaktadır. Bu çatışma henüz iyice bilinir değildir ve çatışan bilgi alanlarındaki bu sorunu çözmeye yönelik çabalar da başarısız olmaktadır (Zaman, 2012, s. 143).

İslam ekonomisi çalışmalarının başarısız olmasının nedeni, modern ekonominin epistemolojik ve sosyo-tarihsel temellerini yani kökündeki meta-ilkeleri başarılı bir şekilde kapatamadan onları İslam'ın normatif pozisyonuna göre dönüştürememesidir. Al-Attas'a göre, bilginin İslamileştirilmesi için modern ekonominin kökünde yer alan felsefi temeller İslam'ın metafizik ve değerbilimsel (axiological) çerçevesine göre kritik bir şekilde ayarlanarak yerleştirilebilmesi gerekir (Jha, 2013, s. 171).

Bazı araştırmacılar ise İslam ekonomisi ile ilgili çalışmalarda stratejik vizyon eksikliği sorunu olduğu tespiti yapılmıştır. Buna göre, teorileştirilme çabalarının metodolojik olarak doğru olmadığı, aslında yapılması gerekenin "islam ekonomi teorisi" değil, "ekonominin İslami teorisi" olduğu iddia edilmiştir. Bunun için de 
insanın ekonomik davranışının incelenmesi gerektiğinden İslam ekonomisinin bu sorunu çözebilmesi için öncelikle fizik ve matematik gibi pozitif fenlerden boşanarak biyoloji, sosyoloji, psikoloji ve felsefe gibi insan yaşamını konu edinen bilimlerle evlenmesi gerektiği savunulmuştur (Khan, 2013).

İslam'ın kendisine has karakteristiği olmasından dolayı modern ekonomi yaklaşımından temelinde ayrıştığı iddiası çerçevesinde yapılan bir araştırma sonucunda "Islâm'ın bütünlüğü nazar-ı itibara alınmadan ve İslâm bütün boyutlarıyla hayata taşınmadan yapılan iktisat çalışmaları, "islâm kapitalizmi" veya "faizsiz ve zekâtlı kapitalizm" olmaktan öteye geçemeyeceği" sonucuna varılmıştır (Çayıroğlu, 2014).

Konuyla ilgili eleştiri yapanlardan bazıları çok ileri de gitmişlerdir. Örneğin Sohrab Behdad, İslam ekonomisinin İran'da uygulama teşebbüsleri hakkında bahsederken "İslam ekonomisinin geçerli bir sosyal alternatif oluşturma kabiliyetinden yoksun olduğu açıkça ortadadır" şeklinde ifade kullanmış ve Timur Kuran da benzer şekilde İslam ekonomisinin öz ve içerikten yoksun olduğunu ve İslam ekonomisi çalışmalarının da aslında farklılaştıııımış bir İslam kimliği oluşturma çabaları olduğunu ileri sürmüştür (Zaman, 2012, s. 145).

Müslüman toplumların geri kalmışlıklarının nedenleri üzerine daha pek çok analiz yapılmışır. Ancak ekonomik sorunların çözümü için genelde çeşitli politika paketleri ile kurumsal yapılar üzerinde durulurken İslam ekonomisinin çözüm sağlama kabiliyetinin göz ardı edilmesi bir sorun olarak ortaya çıkmaktadır. Buradaki sorun modern iktisadın öğretileriyle İslami perspektifle analiz yapmak ile ilgili eksiklik olduğu bir problem olarak kabul edilmektedir.

Üretim, büyüme ve sosyal refah bir birileriyle ilişkili kavramlardır. Üretim arttıkça ekonomik büyüme elde edilir ve bunun uzun dönem sonuçları ise sosyal refaha yansıma şeklinde meydana gelmektedir. Sosyal refahın olmadığı ancak üretim ve ekonomik büyümenin devam ettiği yerlerde otokrasi veya monarşi olduğu varsayılır ve uzun dönem için bunun devam ettirilebilmesi olanaklı da değildir. Pür liberal bir ekonomide bu mümkün değildir. 
Sürdürülebilir bir iktisadi büyüme ve dünya piyasalarında rekabet edebilecek şekilde yenilikçi üretim modellerini uygulayabilmek için sosyal refahın olması ve insanlarının huzurlu bir şekilde yaşaması ve çalışması gerekir. Aksi durumda insan motivasyonu bozulacağından veya gelir düzeyi iyileşen kimseler farklı ülkelere göç edeceğinden dolayı ulusal piyasadaki dinamikler bozularak büyüme tersine dönecektir. Ancak sosyal devlet uygulamalarında olduğu şekilde devlet bütçesine büyük bir yük getirilmiş olması da sürdürülebilir değildir. Bu da vergilerin arttırılması ve dolayısıyla üretim maliyetlerinin yükselmesi anlamına gelmektedir. Ayrıca zenginlerin yasal açıklardan yararlanmaları ve iyi mali müşavirler istihdam etmelerinden dolayı gelir vergisi ile kurumlar vergisi sürekli azalma gösterirken stopajalar ile ücretlerden alınan vergilerin artmasıyla sosyal refahı bozucu unsurlar gelişebilecektir. Bu nedenle de üretim, ekonomi ve sosyal refah konularının İslami perspektifle ele alınarak buradaki soruna bir çözüm elde edilip edilmediğinin tartışılması önem arz etmektedir.

\section{Din Kültürü ve Ekonomi}

Karl Marks kadar farklı olan Max Weber ve Robert Barro gibi ekonomistler ekonomik organizasyon ile din arasında ilişki olduğuna işaret etmişlerdir. Weber, öncelikle Hristiyanlık ile ilgiliyken Barro ise bakış açısını İslam'ı da dâhil edecek şekilde genişletti. Hz. Muhammed'in ilk ekonomist olduğunu iddia eden Koehler'e göre $O$, dini çağrısını 20-30 yıllık ticari müteşebbislik hayatından sonra yaptı. Onun kişisel altyapısı ve iş dünyasındaki faaliyetlerinin iş ve piyasalara yaklaşımını etkilemiş ve bu zamanla İslam ekonomisine dönüşmüştür. Çin, Hint, Afrika ve Avrupa'ya bağlana İslami ticaret askeri ve politik konulardan daha az dikkat çekmektedir. Hâlbuki Akdeniz antik zamanından Dünyanın ilk gerçek anlamdaki küresel ticaret sistemine geçiş sürecinin aslında ekonomist Hz. Muhammed'in ekonomik anlayışından geldiği iddia edilmektedir (Koehler, 2011).

Kapitalizm ve bürokrasi ilişkisini dini perspektifle de ele alan sosyolog Max Weber'in "The Protestan Ethic and The Spirit of Capitalizm" isimli kitabının genelinde, dinin toplumlardaki ekonomik ilişkileri ve kapitalistleşme sürecini ciddi bir şekilde belirlediğinin altı çizilmekte ve doğu toplumları ile Avrupa 
örnekleri üzerinde farklı dinlerin toplumsal ve yönetsel gerçeklikleri nasıl etkileyebildiğinin ve kapitalizmin gelişim sürecinde dinin etkisindeki değişimlerin bile analizleri yapılmaktadır (Gundolf ve Filser, 2013, s. 177). Dolayısıyla kapitalizmin gelişim süreciyle ilişkili analizlerde din ve onun kısmen yansıması olan toplumsal felsefeyi yansıtan kültürü dikkate almamak araştırmanın eksikliğini gösterebilir.

Dolayısıyla, aslında dini yaklaşımların ekonomik hayatı ve dolayısıyla kapitalizmin yükselişinin kaynağını oluşturduğu bilinen bir yaklaşımdır. Ancak, kapitalizmin yükselmesinde 16.yy dini dönüşümlerin büyük katkısı olduğu kabul edilse de kapitalizmin yükselme aşamasında da dini değerlerde gerileme olduğu söylenebilmektedir (Wilber, 1974, s. 257). İslam ve Hristiyanlığın karşılaştırmalı olarak modern devlet ve demokratikleşme üzerindeki etkisini inceleyen Minkenberg ise modern demokrasinin köklerinin Hristiyanlığa dayandığını delillerle ortaya koymuştur (Minkenberg, 2007). Protestan teologların görüşlerini inceleyen bir araştırmacı ise, modern Protestan teologların bir taraftan liberteryenleri eleştirilerken diğer taraftan da gayri insani ve ruhsuz materyalizme karşı durduklarını ortaya koymuştur. Bu ikili kritiğin de bireysel özgürlüklerle sosyal kurumların güçlerinin dengelenmesi gerektiğini ortaya koyduğu bunun da modern dinin özü olduğu savunulmuştur (Riis, 1989).

Bir asır boyunca Marksizmi kökleştiren materyalizm felsefesi, önce ekonomik determinizm felsefesine dönüştü ve ardından da yerini kültürel determinizm felsefesine bıraktı (Steigerwald, 2005, s. 71) Kültürel determinizm de bu kapsamdaki analizlerde dikkate alınması gereken önemli bir husustur. Çünkü kültür aslında toplumsal felsefeyi yansıtan ve dini değer ve ritüellerden oldukça etkilenen bir sosyal değerdir. Kültürel determinizm, fakirliğin ve az gelişmişliğin toplumların kendi inanç, tavır ve alışkanlıklarına bağlı olarak içsel bir dinamiği olduğunu ortaya koyar. Tarihsel maddeci yaklaşımlarda din ve kültür de dikkate alınmakta ancak nedensellikten ziyade daha çok araçsallık noktasındaki işlevsellikleri ön planda tutulmaktadır. Dolayısıyla materyalist felsefede merkeze maddi ekonomik bölüşüm alındıktan sonra diğer her şey bölüşümü artırmak için kullanılan araçlara dönüştürülmektedir. 
Clarence Ayres, kültürel determinizm felsefesine dayanan bir ekonomik gelişim felsefesi geliştirmiştir. Buna göre, geniş anlamda kültürel güçler tarafından geçmişte olduğu gibi gelecekte de ekonomik gelişimin yönünün belirlendiği iddia edilmiştir. Bu kültürel determinizm felsefesi, iki önermeye dayanmaktadır: birincisi teknolojik yenilikçiliği kendi içsel dinamikleri tarafından yönetilen bir kültürel süreç olarak almakta ve bireylerin kahramanca gayretleri ile dehasının yenilikçilik ve icatlar üzerinde hiçbir etkisi yoktur. İkinci önerme ise; teknolojik yenilikçilik tüm ekonomik gelişime neden olan ve onu yöneten dinamik güçtür. Bu teori, Thomas Carlyle'nin kahraman tapıcı büyük tarih adamı felsefesine ve Joseph Alois Schumpeter'in girişimci tapıcı ekonomik gelişim felsefesine alternatif olarak geliştirilmiştir. Çünkü bu her iki teori de elitist olmayan reaksiyonerdirler. Bu teoriler, geleneksel kurumların sosyo-ekonomik ve politik-ekonomik elite atfettikleri üst statü ve özel ayrıcalıkların teyit edilmesinde kullanılırlardı. Fakat Ayres, kurumsallaştırılmış statü ve ayrıcalıkların meşruiyetini inkâr etmek için kendi icat ettiği ekonomik gelişimde kültürel deterministik felsefesini kullanmıştır (Hill, 1989, s. 466).

\section{5. İslam Şeriatı ve Ekonomi}

Sürdürülebilir iktisadi kalkınmanın İslam ile olan ilişkisi üzerinde araştırmalar yapmış olan Marsuki'ye (2009) göre ise din, Dünyadaki pek çok toplumda uygulanan en hükümran etik sistemlerden birisidir. Çağdan Müslüman bilim adamlarına göre, İslam sürdürülebilir ekonomik kalkınma için kendisine has yaklaşımlara sahiptir (Marsuki, 2009, s. 22). Dolayısıyla din, kültür, inanç ve kabuller toplumsal ve yönetsel düzenleri temelinde etkileyen en önemli parametrelerdir. Bu parametrelerin felsefe boyutunda davranışları nasıl etkilediği ve özellikle Müslüman Türk toplumu özelinde İslami temel değerlerin etkileri üzerinde analizlerin yapılması gerekir. Çünkü din ve inancın etkisi gerçek iman ile gerçekleşebilir.

Dinin koyduğu ilke ve prensipler insanın kendisine ait olan varlıklardan fedakârlık yapmayı, başkasının yararına çalışmayı, karşılıksız vermeyi ve kendi egosunu tatmin etmekten kaçınmayı gerektirdiğinden dolayı bunların felsefi temellerinin incelenmesi bir zorunluluk haline gelmektedir. Görünmeyene 
inanmak da başlangıç ve sonuçları itibariyle felsefi parametrelere dayanmaktadır. İlk kabuller ile daha sonraki sonuçlarını hazmetmek, içselleştirmek ve gerektiğinde acı ve ıstırap çekmek pahasına da olsa sabrederek karşılayabilmenin maddi ölçütlerle ve tarihsel materyalizmle anlaşılması olanaklı değildir. Bu nedenle de özellikle Müslüman toplumlarda İslam'da Şeriat, ekonomi ve felsefe ilişkilerinin anlaşılması gerekir.

Kuşkusuz İslam, hayatı tarafsız bir bakış açısı ile inceler. Bu hayatın yapıcı unsurlarının birbirlerini tamamlayıp, birbirlerine destek olduklarını görerek ona göre kıymet verir. Bu unsurlardan bir kısmı bir yana itilerek bir kısmına da haddinden fazla değer verilmemiştir. Hepsi aralarında dayanışma ve ahenk içindedirler. Maddi yön, desteğini ruhi yönden alır. Şu halde İslam'ın makro ve mikro alanlara da tasnif edilebilecek iktisadi prensipleri, diğer ahlaki, sosyolojik, felsefe ve pedagojik prensiplerle iç içe kaynaşmış bir haldedir. Dolayısıyla, İslam'ın iktisadi ve sosyal hayatta mükemmelliği netice verme potansiyelindeki ilkeleri, insan varlı̆̆ının gerçek değerinin farkına varamamıs seküler veya diktatör bir hükümetin baskısı olmaksızın uygulanması imkansız olan ütopik teorilerden ibaret olmayıp, aksine tamamen uygulamaya ve pozitif sonuçlara yönelik olduğunu tarihteki harika örnekleriyle göstermiştir.

"İslam" kelimesi barış, selamet ve iyilik manasında ve "iktisat" ise tasarruf etmek, ölçülülük ve dengelilik anlamın taşıyan Arapça kelimelerdir. İktisat yerine kullanılan "Ekonomi" ise Eski Yunan kökenli bir kelimedir. "İslam Ekonomisi" veya onun yerine kullanılan "İslam İktisadı" ise İslami değerlerden esinlenen bir toplumun İktisadi sorunlarını inceleyen sosyal bir bilim dalı olarak tanımlanabilir. "İslam İktisadı" ile daha çok kaynağını veya esintisini İslam'dan alan ekonomik faaliyetler ve müesseseler kastedilmektedir. Akademik anlamda İslam Ekonomisi veya İktisadı ise, Modern Iktisat öğretilerindeki bazı varsayım, parametre ve ekonomik birimlerin davranış farklılığı dışında başka bir ayrılığı söz konusu olmadığından dolayı İktisat biliminin kullandığı, analiz araçları ve modelleme yöntemleri ile kavramları da kullanacağından dolayı İktisat Biliminden bağımsız ayrı bil disiplin olarak düşünülemez. Bu nedenle, İslam İktisadının bilimsel olarak İktisat Biliminin farklı bir yorumu veya bir alt dalı olarak ele alınması mümkündür. 
"Şeriat" diye adlandırılan İslam Hukuku temel olarak dört ana daldan oluşmaktadır. Bunlar şunlardır:

- Itikat Esasları: İnanç ile ilgili hükümleri içerir.

- Ibadet Esasları: İbadet ile ilgili hükümleri içerir.

- Ukubât Esasları: İslam Ceza Hukukunu içerir.

- Muamelât Esasları: İnsanların birbirleri ile olan davranışlarını düzenleyen kural ve esaslar bütünüdür. Kısacası, sosyal hayat ile ilgili düzenlemelerden ibarettir.

İşte İslam ekonomisi veya iktisadı, özünde olarak İslam hukukunun "Muamelat" gurubuna dâhil olan kural ve müesseseleri ifade etmektedir. Yani İslam Ekonomisi, İslam hukukunun iktisadi tarafı ile meşgul olan, özünde normatif ama pozitif dayanak ve maslahatlara dayanan bir sosyal bilim dalı olan iktisat biliminin bir alt dalı olarak kabul edilmektedir. Buna göre, İslam` ın ekonomi alanındaki düzenlemeleri "İslam Ekonomisi" ni teşkil etmektedir. İslam hukukunun bir alt dalı olduğundan bazen "El-fikh-ul iktisat" diye de tabir edilmiştir.

İslam ekonomisi kapsamında değerlendirilebilecek çalışmalar, Gazali, İbn-i Haldun ve İbn-i Kayyım zamanına kadar inmektedir. Diğer bir değişle, daha iyi organize edilmiş ve çağdaş İslam ekonomisi paradigması, özellikle Müslüman ülkelerin koloni sonrası dönemde bağımsızlıklarını kazanmalarından sonra 20.yy. ikinci döneminde ortaya çıkmıştır. İslam ekonomisi temel bilgilerini Kuran, sünnet, icma, kıyas ve içtihat denilen beş ana kaynaktan almaktadır (Aström, 2011).

Bir bağımsız disiplin olarak İslam ekonomisi, sistematik bir kaynak ve dayanağa ihtiyaç duyduğundan dolayı kaçınılmaz olarak İslami teoloji ve hukukla bağlanmıştır. Her nasılsa İslam ekonomicileri ile şeriat âlimleri arasındaki düşünsel etkileşimde eksiklikler mevcuttur. İslam ekonomicileri finansman ve geniş ölçekli risk paylaşımına dayanan katılımsı finansal sistem modelleri ile gelirken İslam fıkıhçıları ise daha çok geleneksel araçların kullanımı veya Şeriata uygun olan türevlerle ilgilenmektedirler. Bu çabalar da İslami finansmanın geleneksel statükoya yanaşmasına ve finansal aracılığın alternatif sistemlerinden uzaklaşmaya neden olmuştur. Ancak bu durum İslam ekonomisinin yeni bir paradigma olarak gelişmesine katkıda bulunmamasına rağmen süreç tersine çevrilebilir (Nienhaus, 2013, s. 169). 
İslam ekonomisinin kişisel şuura bağlı bir değer merkezli disiplin olduğu iddia edilirken bunun aynı zamanda pozitivist objektiflik ve değere karşı tarafsız bir iklimde ekonomik teori ve politikaların yerleştirildiği düşünceleri de reddetmektedir. İslam ekonomisi, dini etik değerlerin kaynağı olarak kabul ederek etik ve dini yaklaşımları kendi teorik ve aynı zamanda politikasında birleştirmeyi hedeflemektedir. Ancak çağdaş İslam ekonomisi çalışmalarından çok azında bu şekildeki bir yaklaşımla etik değerler ekonomik analizlere dâhil edilmektedir (Haneef ve Furqani, 2009).

İslam ekonomisi, diğer iktisadi sistem ve kuramlardan farklı bir şekilde, dini değerlerle iç içe olan kendine has bir karakteristiğinden dolayı, ilkeleri ve kurumları birey odaklı olup, bireylerin yaşadığı ortamdaki felsefi, psikolojik ve sosyolojik yapı ile yakından ilgilidir. Diğer bir deyişle İslam Ekonomisi; İslam'ın insanın maddi ve manevi yetenek, imkân, ihtiyaç ve hedeflerine birden hitap etmesinden dolayı, samimi bir şekilde kabrin öbür tarafına yönelerek inanması gerektiği gibi inanan ve inandıklarının gereklerini samimi olarak yerine getirmeye çalışan insanların toplumdaki oranına bağlı olarak ortaya çıkan davranış şekilleri ve yaşam biçimlerinin yansımasının teorik ifadesi olmaktadır. Bu nedenle, konunun daha iyi anlaşılması için bilimsel olarak İslam ekonomisinin özellikle din, felsefe, felsefe ve sosyoloji disiplinleri ile olan irtibatı, bu bilim dallarının İslam'ın ekonomik modeli olan müminin ekonomik davranışlarını nasıl etkilediğini ve İslam'ın iktisadi prensiplerinin bu temellere neden ve nasıl oturtulduğunu incelemekte büyük yarar vardır.

İhtiyaçlarla mevcut imkânlar arasında dengeli bir yaşamı tesis ve kontrol eden müesseselerin başta geleni muhakkak ki dindir. Din, israfı yasaklayarak insanı hakiki ve zaruri ihtiyaçlarının temini için meşru yollarda çalışmaya sevk eder. İslam` da din, yaşantının tüm örgüsünü kapsamakta olan kuşatıcı bir çerçevedir. İslamiyet, hayatın her bir yönünü ele aldığı zaman onu din ile birleştirir ve onu insanın kendi yaratıcısı ve ahretiyle olan dini bağlantı çerçevesinde kalıba döker. Din, kişisel içgüdüleri genel toplumsal çıkarlar hesabına güçlendirerek sosyal problemleri çözümleme konusunda başrolü oynamaktadır. 
İslam, ekonomik gelişme ve refah için bir model insan portresi önermediği gibi, sadece en uygun insan modelini mahsul verecek ilkeleri koymakla yetinmiştir (Ansari, 1994, s. 398). Evet, İslam'a göre insanın hayatındaki temel problem, yaradılısı ve dolayısıyla genetik kabiliyet ve duyguları ile ilgilidir. Çünkü bu problem, kişisel içgüdülerin birbirinden farklılık göstermelerinden dolayı, ihtiyaçların giderilmesinde insanın mutluğunun çoğunlukla genel toplumsal çıkarlar ile çelişmesinden kaynaklanmaktadır. Çözüm yolu olan dininden kasıt ise saf, katıksız olan tevhit dinidir ki bu din, kişisel içgüdüler, bireysel ihtiyaçlar ile genel sosyal çıkarlar ve pratik sonuçlar arasında bir uyum sağlayabilmekte ve insanın kendisi ile bütün varlıkların barış içerisinde yaşamasının anahtarlarını vermektedir. İnsanın felsefi, psikolojik ve sosyolojik düşüncelerine göre şekillenen ve bütün hayatı örgüleyen sosyal düzenin bir parçası olması niteliğiyle İslam Ekonomisi de, bu düzenin genel çerçevesi ve yansıması olarak ortaya çıkmaktadır.

Bugün iktisadi açıdan kabul edilen şudur ki; toplumsal kalkınma, maddi ve manevi veçheleri ile sosyal, kültürel, ahlaki ve hukuki bünyesinde gelişmenin iktisadi bir sonucu ancak olabilir. Manevi ve ahlaki cephesi ile kültürel ve sosyal cephesi gelişmemiş bir cemiyetin sırf iktisadi cephesini kalkındırmak mümkün değildir (Nakvi, 1985, s. 27). Durum böyle olunca, ister istemez aslında birbiriyle barışık, birbirinin kaynağı ve dayanağı olan madde ve mana üzerine birlikte eğilmek, cemiyetin iktisadi bünyesi ile birlikte sosyal, kültürel ve ahlaki bünyesini incelemek gerekmektedir.

Refah toplumu olmak gayesi, dinin bünyesinden çıkan ahlaki ve manevi değerlerin kontrolüne mutlak anlamda muhtaç olduğu gibi, İslam'da refah toplumu, Dünya imtihanını yani ahretini kaybetmemek amacıyla Allah rızası yolunda çalışmanın bir sonucu olarak ortaya çıkabilir. Çünkü Allah yolunda çalışmak sadece klasik anlamdaki ibadet veya dua etmek ile sınırlandırılamadığı gibi, aslında gerçek iman sahibi bir Müslüman için neticesi itibariyle güzel olan her iş, her hareket ve uygulama ibadet ve dua anlamını taşır ve ortaya çıkan her sonuç da bir şükür, dua ve ibadet neticesi ve nedeni olarak görülür. Bu da iyi ahlakın en yüksek derecesidir. Dolayısıyla, iktisadi hayatta "Homo Economicus" modeli aşılanarak ve hiçbir ahlaki değeri olmaksızın maksimum kar ve fayda peşinde 
koşturularak ahlak faktörü ihmal edildiği takdirde, itimatsızlık, merhametsizlik, hile ve yalan gibi mevhumlar menfaat duygusuna yön veren esaslar olur ve bu ahlaki ve manevi zaafların bir sonucu olarak, iktisadi yapının unsurları durumundaki sosyal dayanışma ve toplumsal emniyet ortadan kalkar. Ayrıca, ahlak ve dolayısıyla sosyal sorumluklar ihmal edildiğinde gelir dağılımındaki adalet de bozulmağa yüz tutar. Bu nedenlerden dolayı, ahlaki ve manevi değerlerin kaynağı olan din kavramını, toplumların iktisadi sorunlarına yön veren bir sosyal dayanışma ve istikrar unsuru olarak görmek gerekir.

Müslüman ülkelerde ciddi ekonomik krizlerin olması ve teorik olarak İslam ekonomisinin başarılı görünmemesinin temel sebebi üzerinde yapılan araştırmalarda, bunun asıl nedeninin çoğu Müslüman ekonomistin gerçek imana sahip olmamasından dolayı kapitalist batı toplumlarında üretilmiş ideolojileri çok sorgulamadan kabul etmelerinden kaynaklandığı ortaya konulmuştur (Zaman, 2012). Bu nedenle de İslam'ın inanç ve yaşayışının temel dinamikleri ve ilkelerinin ana kaynağı olan düşünsel ve felsefi alt yapısının analiz edilerek buna göre bir çözümleme yapılması ihtiyaç olarak görülmektedir.

\section{Faizsiz Ekonomide Büyüme}

Büyüme, başka faktörler yanında belirli bir dönemde üretilen fiziki mallar ile hizmetlerin miktar olarak artışını ifade etmektedir. Faiz alarak aşırı büyüme hırsıyla hareket edildiğinde ise en ufak bir tökezlemede iflaslar baş göstermekte ve ekonomide beklentiler üretimle birlikte düşmeye başlamaktadır. İslami bir ekonomide her şeye rağmen büyüme bir amaç değil, fakat toplumun iyi yaşam düzeyine terfi etmesi için kullanılacak bir araç olarak görülmektedir. Kaynaklar israf edilmeden insanlık yararına seferber edildiğinde sonuçta sürekli büyüme ortaya çıkacaktır. Peki, böyle bir ekonomide büyümeyi hangi faktör açıklar. Burada, İslami büyüme modelinin fiziki değerler yanında moral değerler üzerine de bina edildiği seküler sistemdekilerden oldukça farklı hipotezler üzerinde durulmuştur. Fakat, bu bakış açısını uygun görmeyenler ampirik verilerle düşüncelerini ispat etmeye çalışmışlardır. Örneğin ABD ekonomik dataları üzerinde yapılan bir ampirik çalışma, büyümeyi açıklayan faktörlerden sadece yarısının "fiziki faktörler" olarak 
gösterilmesine rağmen, hata terimleri içinde saklanan açıklanamayan bağımsız değişkenleri Denison, "ölçümdeki bilgisizliklere" bağlamıştır.

Çoğu Müslüman ekonomistler, büyüme üzerinde etkili olduğunu düşündükleri moral değerleri farklı şekillerde ele almışlardır. Birliktelik ruhu, hamiyet, kültürel şevk vb. ile Müslümanları geçmişteki üstünlüklerini tekrar elde etmeye çağırmışlardır. Bu çalışmada ise "ihlas"ın bir neticesi olarak "Ihsan-ı Illahi", sürdürülebilir ekonomik büyümede bir faktör olarak değerlendirilmek istenmiştir. Buna göre bu faktör, ekonomik büyümeye gerekli bazı kurumsal düzenlemeler ve uygulamalar kanalı ile takva (Allah korkusuyla menhiyatlardan çekinmek ile emir dairesinde hareket etmek) sayesinde otomatik stabilizator şeklinde işlev görebilmektedir.

Bu konularda ampirik çalışmaları engelleyen faktör, kuşkusuz ekonomik verilerin eksikliğidir. Bu nedenle, Kuran ve Sünnet ışığında ilkeler mantık çerçevesinde teorik olarak tartışılmıştır. Analitik sonuçlar, moral faktörlerin hem büyüme ve hem de gelir düzeyi üzerinde pozitif etkilerde bulunabildiğini ortaya koymuştur. Bu model önemli ekonomik etkileşimleri genellemektedir.

Bu alanda çalışan ekonomistler farklı görüşlere sahip olabilmişlerdir. Klasik yaklaşıma göre; kalkınmayı tasarruf, yatırım ve teknolojik gelişmeler sağlar. Siddiqi (1983) kalkınmayı "fazlalık değerlerin sosyalize edilmesi" süreci olarak görür ve İslam'ın bunun için yeteri kadar motive edici iç dinamikleri olduğu üzerinde durur. Sadeq (1989), İslami ekonominin, yoksulluğu ortadan kaldıracak ve gelir ile varlıklarda büyümeye yol açacak göçlü saikler üzerinde durmuştur. Bu amaçla İslam, çalışmaksızın tevekkül etmeyi ve tembelane kanaati yasaklar ve sürekli ekonomik aktiviteye teşvik eder ki, bu aktivitelerde bulunanların -kesb edenlerin"Allah'ın sevgilisi" olarak nitelendirildiği görülmektedir. Büyüme faktörleri alanında, doğal ve beşeri kaynaklar yanında özellikle araştırma ve geliştirme faaliyetleri üzerinde durulmuştur.

Başka bir kategori, İslam'ın moral değerlerinden kaynağını alan motive edici güçler nedeniyle kalkınmanın din tarafından sağlanan bir süreç olduğudur. 
Kalkınma potansiyeli insani değerlerde yatmaktadır. İslami politikalar, her Müslüman birey ve toplum için en önemli amaç olması gereken ruhi eğitim üzerinde odaklanmıştır. Çünkü dünyada biriktirilen mal ve servet neticede ölümle birlikte bırakılmaktadır. Ortalama olarak günde 150.000 insan öldüğü dikkate alındığında her gün ölebileceği gerçeğini hatırlayan insanlar, belirli bir noktadan sonra büyüme yolunda çalışmayı terk ederek zevk ve sefahate atılarak ölümü unutmaya ve kendisini avutmaya çalışacaktır. Ancak İslami modelde insanların gerçek mutluluğu kendisinin geçici olarak dünyada bulunduğunun şuurunda olarak kendisine emanet olarak verilen varlıkları en iyi bir şekilde kullanmak ve insanlık hayrına çalışma noktasındaki gayretine göre derece kazanacağını düşüneceği için teknik olarak üretimin aksaması veya hırsla hareket ederek aşırı büyüme eğilimi göstermeyeceğinden dengesizlikler meydana gelmeyecektir. Bu da kişilerin sahip oldukları tahkiki imanın kuvvetine göre değişebilecektir.

\section{Ekonomik Büyüme Modeli ve Üretim Fonksiyonu}

Seküler sistemlerde toplam üretim seviyesindeki değişmeler, büyüme için esas değer olarak kabul edildiği gibi, İslam'a göre üretim fonksiyonu değerlerinde farklılık söz konusu olabilmektedir. İslami bir ekonominin üretim sepetinde hem maddi ve hem de manevi ihtiyaçları tatmin edecek materyaller vardır. Maddi üretim ve hizmetler gibi akıl rahatı, iç huzuru ve ebedi mutluluk gibi maddi olmayan faktörler vardır. En önemlisi de kendisini yoktan yaratarak kainatı kendisine hizmetkar eden ve edebi saadet için imtihana çekerek muhabbetine celb eden Allah'ın rızasına kavuşmak en büyük kuvvet ve dayanak noktası olarak dikkate alınmalıdır. İslam’ın gösterdiği yolda anlamlı ve mutlu bir yaşam için her iki hayat için gayret etmeye ihtiyaç olduğu ortaya konulmaktadır. Ancak, niyet, nazar ve eşyanın yaratıcıları ile olan ilişkilerine göre yaklaşım sergilendiğinde her türlü dünyevi eylem ve faaliyet de Allah hesabına olarak ahiret kazancını artıııc bir unsur olarak ele alınmaktadır. İşte bu maddi sonuçların da daha yüksek bir düzeyde gerçekleşmesini sağlayacağından olayı, topyekün büyümeyi sağlayacak potansiyel olarak değerlendirilmelidir. 
Müslüman ekonomistler, büyüme sürecinde bu faktörün önemine değinmişlerdir. Moral faktörler, doğrudan veya dolaylı olarak üretim düzeyinin yükselmesine yardımcı olur. Moral faktörlerin ikisi de insanın iman gücüne bağlıdır. Buna göre üretim fonksiyonu şu şekilde oluşturulabilir: Fiziki değerler, İşgücü, Sermaye ile teşebbüs ve Allah İhsanı (iman gücü ve ihlas).

1- Fiziki Değerler: Bu faktör, üretim aracı olarak tekrar kullanılabilen malzeme ve ekipmanı içerir. Bu da; Allah'ın bir ihsanı olan toprak ve mekanik sermaye, kiralanabilir varlıklar ve amortismanlar'dan oluşmaktadır.

2- İşgücü: Üretime yaptığı katkı kadar, yani verimlilik esasına göre ücreti belirlenen işgücüdür. Önceki bölümlerde incelendiği gibi, "üç insan mahşerde perişandır. Birisi odur ki işçinin hakkını tam olarak vermez.." ve "iş̧̧inin hakkını alın teri kurumadan tam olarak verin" gibi emirler, işgücünün motivasyonunda ve istihdamında etkili olmaktadır. faizle çalışanların gelirlerine el konulmadığından ve sermayedarların zekatları ile emekçilere yardım etmelerinden dolayı iş̧̧i-işveren mücadelesi de olmayacaktır.

3- Sermaye ve Teşebbüs: Üretim sürecini finanse eden ve üretim çarkını çalıştıran faktördür. İslam öğretisine göre, sermayenin risk paylaşımı üzerine yapılan sözleşmelerle üretim sürecine alınması gerekir. İslam, sermayenin fiyatı olarak faizin verilmesini yasaklamış olup, kârı muharrik unsur olarak kabul etmiştir. Sermayedarların banka mevduatları üzerinden çalışan kesime verilen kredilerden garantili para kazanmaları yasaklanmıştır. Bir nevi "sen çalış ben yiyeyim" düzenini ortadan kaldırdığı için sermayedar sürekli reel kesime yönelmekte ve üretim ve büyümeye olumlu katkıda bulunan gelir getirici faaliyetler peşinde koşmak durumundadır.

4- Allah ỉhsanı (İman kuvveti ve ỉhlas): Allah'a ve sonsuz rahmetine inanmak, İslam inancının temelidir. Rahmet, Allah'ın kainatın her tarafında tecelli eden ve her tarafı kuşatan en büyük sıfatlarındandır. Buna göre, Allah'ın rahmeti insanın yaratılışından ölümüne kadar ve bütün mevcudat ile her şeyi kaplamıştır. Her şey onun rahmetine muhtaçtır. Çünkü hiçbir sebebin kendi başına iş yapma kudreti 
yoktur. Her iki dünya saadeti bu faktöre bağlanmıştır. Buhari'nin rivayet ettiği bir hadise göre; "Hiç kimse kendi ameli ile ebedi hayatı kazanamaz ancak, Allah'ı́n fazl ve ihsanı olarak ebedi hayat verilir". Çünkü insan yokluktan yaratıldığından Allah'a karşı hiçbir hak iddia edemez, ömür boyu ibadet etse, gene verdiklerinin karşlığı bile olamaz. Allah dilediğine arttıır dilediğine de azaltır. Az iken şükrederek helal kazanç peşinde koşarak fiili dua etmek ve çok iken de zekat ve sadakasını vererek elde ettiklerini insanlık hayrına üretim ve istihdam oluşturacak sektörlerde sarf ederek şükrünü eda ederek Allah'ın ihsanına erişmiş olacaktır. Kuran da "lein şekertum leezidennekum" şeklindeki ayetlerle şükrün artmasının çoğaltıcı bir faktör olarak dikkate alınabileceğine dair çok işaretler verilmektedir. Şükrün ölçüsü de kanaat, helal kazanç, iktisat ederek harama girmemeye dikkat etmek olarak belirlenmektedir.

"Şükrün mikyası; kanaattır ve iktisaddır ve rızadır ve memnuniyettir. Şükürsüzlüğün mizanı; hırstır ve israftır, hürmetsizliktir, haram helâl demeyip rastgeleni yemektir. Evet hırs; şükürsüzlük olduğu gibi, hem sebeb-i mahrumiyettir, hem vasıta-i zillettir" (Nursi, 1960, s. 366).

Kuran, refahları ve ekonomik kalkınmışlıkları Allah'ın rahmetini geri çekmesiyle son bulan "Ad" ve "Semud" kavimlerini örnek vererek, insanlara kâinatta büyük örnekleri görünen ve kendisini sevdirmek isteyen rahmet ve ihsana uygun olarak hareket etmelerini emreder. Allah'ın rahmetini arttıran en önemi faktörler; her şeyi Allah'ın rızasını kazanmak için yapılması anlamında olan "ihlas", kendi imkânları ile elinden geleni yaptıktan sonra gücü yetmeyen hususlarda neticeyi Allah'tan beklemek anlamında olan "tevekkül", ibadete devamda, yasaklardan kaçınmakta ve musibetlere tahammülde uygulanması gereken "sabır" ve kainattaki umumi rububiyyet ve rahmete karşı minnettar olmak ve iktisatla nimetin kadrini bilmek anlamında "şükür" olarak ifade edilen, tahkiki bir imanın neticeleri olarak ortaya çıkan ve birbirilerini etkileyen çeşitli faktörlerdir. Yani, Allah'ın rahmet ve ihsanının artmasına vesile olan bu unsurların hepsi, insanın Allah'ı tam olarak tanıması anlamında ve ilmel-yakin, aynel-yakin ve hakkal-yakin mertebeleri olan tafsili bir "tahkiki iman" a ve bununla yakından ilişkili olan ve rivayetlerde "En büyük bir kuvvet ve vesile-i makasıt" olduğu belirtilen "ihlas" ile bağlı ve doğru orantılıdır. Çünkü Allah, bana bir gelene ben on gelirim demiştir. 
"...en mühim bir esas, en büyük bir kuvvet, en makbul bir şefaatçı, en metin bir nokta-i istinad, en kısa bir tarîk-ı hakikat, en makbul bir dua-yı manevî, en kerametli bir vesile-i makasıd, en yüksek bir haslet, en safi bir ubudiyet: İhlastır" (Nursi, 1956, s. 159).

Üretim fonksiyonunda açıklanamayan bağımsız değişkenler içinde olması gereken bir faktör de (Akthar, 1993) kurumsal varlık ve düzenlemelerdir ki, bu da Allah'ın ihsanını arttıran faktörler içerisine alınmıştır. Bunlar, manevi eğitim fonksiyonu yanında, insanlarda toplumsal bilinç ve kamu yararını aşılayan cemaat ruhu ve "cami" ile adalet ve asayişi sağlamak için yapılacak düzenlemeler ve uygulamaların "kamu otoritesi" tarafından yapılmasıdır. Bunların, Allah'ın rahmet ve ihsanını arttırdığını gösteren en önemli ve inkâr edilemez olduğuna delil, "asr-ı saadet" ve peygamberden sonraki 30 yıllık cumhuriyet ve hilafet dönemi ve o dönemdeki refah, düzen ve adalettir ki kısa sürede çok farklı milletleri kapsayan büyük alana yayılarak Müslüman olmayanların da refaha kavuşmasını sağlamıştır (Choudhury, 1991).

Bu kısımdaki açıklananları şu şekilde özetleyebiliriz:

$Y t=Y(P t, K t, L t, F t)$

$Y \mathrm{t}=\mathrm{t}$ zamanındaki çıktı düzeyi,

$\mathrm{Pt}=\mathrm{t}$ zamanındaki üretime katılan toprak ve teknik aletleri içeren fiziki varlıkların değeri,

$\mathrm{Kt}=\mathrm{t}$ zamanındaki parasal sermaye ve teşebbüs imkânları,

$\mathrm{Lt}=\mathrm{t}$ zamanındaki işgücü,

$\mathrm{Ft}=\mathrm{t}$ zamanındaki Allah'ın ihsanı ve rahmetini attıran moral faktörler.

Yukarıdaki (1) nolu fonksiyon, t zamanındaki üretim seviyesinin fiziki ve moral değerlerin bir fonksiyonu olduğunu göstermektedir. Ft bağımsız değişkeni, Yt bağımlı değişkeni üzerindeki doğrudan etkisi yanında, diğer fiziki bağımsız değişkenler üzerinden de dolaylı etkiye sahip olmasından dolayı toplam türev yoluyla toplam etki hesaplanabilir. 
$\mathrm{Lt}=\mathrm{L}(\mathrm{Ft})$

$\mathrm{Ft}=\mathrm{F}(\mathrm{Tt})$

$T t=T(I t)$

$\mathrm{Tt}=\mathrm{t}$ zamanındaki moral değerleri temsil eden "ihlas",

It = t zamanındaki "kurumsal düzenlemeler",

(1) den (4) e kadar toplam türevleri alındığında;

$d y / d t=Y p(d p / d t)+Y k(d k / d t)+Y L(d L / d t)+Y f(d f / d t)+$

$$
+Y L[(d L / d t) .(d f / d t) .(d t / d t) .(d l / d t)]
$$

bu derivasyondan,

$Y=Y p P+Y k K+Y L L+Y f F+Y L L^{\prime}$

elde edilir.

$L^{\prime}=[(d L / d t) .(d f / d t) .(d t / d t) .(d l / d t)]$,

işgücünün moral değerlerle veriminin artmasıyla elde edilen türemiş işgücü arzını ifade etmektedir.

Yukarıda (5) numara ile gösterilen denklem, fiziki değerler, sermaye, işgücü ve moral değerlerin "Marjinal Fiziki Ürününü" vermekte olup, ürün üzerindeki moral ve kurumsal değerlerin rolünü göstermektedir. Medine'ye hicretten sonra ekonomik ve sosyal sonuçlarda görüldüğü gibi, burada işgücünün moral değerlerin etkisiyle veriminin artmasıyla ek bir katma değer ortaya çıkması söz konusudur.

(6) Denklemindeki F ve L' değişkenleri, moral değerlerin toplam etkisini göstermekte olup, Allah'ın rahmet ve ihsanını arttıracak olan toplumdaki tahkiki iman ve ihlasın gerekleri olarak ortaya çıkacak olan iktisat, kanaat, sabır, tevekkül, tembellik yapmamak ve toplum yararı için çalışmak gibi hayati faktörlerin derecesine göre pozitif ya da negatif olabilir. İslam toplumlarında bu değerlerin pozitif olmasını sağlayacak iç dinamikler yeterince mevcut olup, bunların bozucu faktörlerle diskalifiye edilmemesi esastır. Yoksa Osmanlı́nın son zamanlarında da görüldüğü gibi, eğitim kurumları dâhil olmak üzere İslam'ın öz değerlerinden uzaklaşılmasıyla, insanların israf, kanaatsizlik, çıkarcılık ile ahlaki değerlerden 
yoksun hale gelerek, Müslüman toplumlarda bu şekil yozlaşmalar neticesinde F ve L' faktörleri büyümeyi önleyecek negatif değerler olabilmektedir.

\section{Mikro ve Makro Çerçevede Sosyal Refah Fonksiyonu}

Burada üzerinde durulacak olan gözlemlenebilir sosyo-ekonomik değişkenler ve sayısal değerler üzerinde ölçülebilir bir sosyal refah fonksiyonudur. Böylece, ele alınacak olan sosyal refah fonksiyonu ölçülebilir olan davranışsal olduğu kadar ampirik bir kardinal fonksiyondur. Refah fonksiyonu parametrelerinden burada üstünde durulan en önemlileri, micro ve makro düzeyde politika aracı olarak kullanılması mümkün olabilen zekât ile kar payı değişkenleridir. Örneğin zekâtın makro düzeydeki etkisi finanse etme fonksiyonundan dolayı toplam harcama düzeyi aracılığı ile gerçekleşirken, zekâtın daha çok üretim sürecini tahrik etmesi ve bu alanda mobilize edilmesi durumunda mikro düzeydeki etkisi daha ön planda olacaktır. Bu bağlamda öncelikle kar payı değişkeni ele alınacak daha sonra zekât konusu açıklandıktan sonra sosyal refah fonksiyonuna geçilecektir.

\section{a- Ağırlaştırılmış ortalama kar payı oranı:}

Spesifik ortaklık projeleri üzerindeki kar payı işlemi de mikro düzeyde değerlendirilirken, makro düzeyde kar payı oranları ve meblağları daha çok makro ekonomik bir değişken ve politika aracı olarak kullanılabilir. Dolayısıyla, ağırlaştııılmış ortalama kar payı oranı bir ekonomik parametre olarak ele alınabilir. Buna göre;

I : proje adedi,

$\mathrm{Pi}$ : i projenin kar payı oranı

$\mathrm{j}$ : katılımcı sayısı

olarak atandığında;

Toplam kar oranı $=(\mathrm{i})(\mathrm{j})[\mathrm{pi} .(\mathrm{K}(\mathrm{i}, \mathrm{j}) / \mathrm{Ki})]$

$\mathrm{i}: 1,2,3, \ldots \mathrm{n} ; \mathrm{j}: 1,2,3, \ldots \mathrm{m}$

Burada $\mathrm{K}(\mathrm{i}, \mathrm{j})$, i proje için $\mathrm{j}$ katılımcı tarafından sarf edilen sermaye miktarını ifade etmektedir. Dolayısıyla;

$\mathrm{K}(\mathrm{i}, \mathrm{j}) / \mathrm{Ki})$, burada $\mathrm{j}$ katılımcının sermaye giderinin i projedeki toplam sermaye giderine oranıdır. 
j) $[K(i, j) / K i]=1$, Buna göre;

Toplam kar oranı $=(\mathrm{i})[\mathrm{pi}]$

Bunu, n sayısındaki proje miktarına böldüğümüzde ortalama kazanç oranı elde edilmiş olur. Böylece, ağırlaştırılmış ortalama kar payı oranları,

$$
\text { pi. }(K(i, j) / K i) \text {, }
$$

$\mathrm{i}: 1,2,3, \ldots \mathrm{n}$,

$\mathrm{j}: 1,2,3, \ldots \mathrm{m}$, bir makroekonomik değişken olarak ortalama kar oranından elde edilen toplam kar oranını vermektedir (Choudhury, 1991).

\section{b- Zekat değişkeni ve refah fonksiyonundaki yeri:}

Yerini kar payına bırakan faiz sisteminin mikro ve makro düzeyde tüketici refahı ile müteşebbis gücü üzerindeki bozucu tesirleri önceki bölümlerde detaylı olarak ele alındı. Bilindiği gibi faiz, oranı servet etkisi ile tüketim fonksiyonunda ve IS eğrisi değişkeni olarak da yatırım fonksiyonunda yerini almaktadır. Piyasa Kar oranı makro düzeyde ve kar paylaşım oranları mikro düzeyde içsel politika değişkenleri olarak tüketim ve yatırım fonksiyonlarını yürütebilecekleri hususu yukarı da ele alınmıştı. Bu değişkenlerin üretim ve refah üzerindeki etkisinin tam olarak ortaya çıkması için israfın da minimum düzeye inmiş olması gerekir.

$$
W=W(x, p, C, E, W, I ; M, Z, i, I, s)
$$

Kardinal bir sosyal refah fonksiyonu kullanılabilir. Bu fonksiyonda; " $x$ " milli geliri, "p" fiyatlar genel düzeyini, "C" tüketim harcamalarını, "E" istihdamı, "W" ücretleri, "I" yatırım harcamalarını temsil etsin.

Bu parametreler sosyoekonomik değişkenler olarak belirlenmiştir ki, bunların içerisine daha çok etken katılabilir. Politika veya aletsel değişkenler olarak da; "M" kar payını, "Z" zekatı, "i" faiz oranını, "İs" israfı temsil etsin (Choudhury, 1991). 
Zekat, üretim sürecine konulmayan belirli düzeydeki servet üzerinden alınan bir gelir transferi olması yönüyle yapısal değişimi de körükler. İsrafın ortadan kaldırılmasıyla zekat gerçek ihtiyaçlar için harcanarak refah etkisi doğurduğu gibi üretim sürecine sokulduğu zaman da büyüme etkisi gösterir. Dolayısıyla aralarında güçlü etkileşim bulunan makro ve mikro düzeyde olumlu etkileri söz konusudur. Gelir, istihdam, eğitim, verimlilik, tasarruflardaki harcama, yatırım ve ihtiyaçlar, fiyatlar ve karlılık, sermaye akışkanlığı, gelir ve servet emniyeti, vb. gibi araçların makro ve mikro düzeydeki sosyo-ekonomik tesirleri arasında mantıklı ve çoklu bir etkileşim ve bağlılık söz konusu olup, bu durum ve yönelim zekâtın artması ve israfın azalması ile olumlu yönde güç kazanır. Burada belirtilmesi gereken önemli bir konu da gelir ve servetin ediniminde ve muhafazasında emniyetin sağlanmasıdır ki, hem meşruluk noktasında ve hem de devamının sağlanmasında emin olunması için gerekli zeminin ve hukuksal düzlemin oluşturulmasını ifade eder.

\section{Sonuç}

Ekonomi insan tercihlerine göre şekil almaktadır. Her tercih insan yaşamını ve hayatının devam ettirilmesiyle ilişkili olduğundan dolayı bir felsefi alt yapıya dayandırılabilir. Kuşkusuz tüketici olarak hane halkının üretici, istihdam edici ve vergi veren olarak yatırımcıların harcama alanları ve miktarları ile ilgili tercihleri ekonomideki sorunları ve çözümleri belirleyen davranışlarına göre makro ve mikro ekonomik değişkeler etkilenmektedir. Her dinde toplumsal yaşamla ilgili, diğer insanlar ve doğa ile olan ilişkileri düzenleyen hükümler az çok mevcut olup bu ilkelerin yaşam felsefesini etkilediği ve bireysel tercihleri etkilediği genel olarak kabul edilmektedir. Bu anlamda dindar insanların da iktisadi hayattaki tercihleri ve ekonomik davranışları değişebileceğinden dolayı üretim, tüketim ve yatırım ile ilgili seçimleri ve etkinlikleri de dini değer yargıları ve felsefeye göre değişim gösterebilecektir.

Üretim, büyüme ve sosyal refah bir birileriyle ilişkili kavramlardır. Üretim arttıkça ekonomik büyüme elde edilir ve bunun uzun dönem sonuçları ise sosyal refaha yansıma şeklinde meydana gelmektedir. Sosyal refahın olmadığı ancak üretim ve ekonomik büyümenin devam ettiği yerlerde otokrasi veya monarşi 
olduğu varsayılır ve uzun dönem için bunun devam ettirilebilmesi olanaklı da değildir. Pür liberal bir ekonomide bu mümkün değildir.

Sürdürülebilir bir iktisadi büyüme ve dünya piyasalarında rekabet edebilecek şekilde yenilikçi üretim modellerini uygulayabilmek için sosyal refahın olması ve insanlarının huzurlu bir şekilde yaşaması ve çalışması gerekir. Aksi durumda insan motivasyonu bozulacağından veya gelir düzeyi iyileşen kimseler farklı ülkelere göç edeceğinden dolayı ulusal piyasadaki dinamikler bozularak büyüme tersine dönecektir. Ancak sosyal devlet uygulamalarında olduğu şekilde devlet bütçesine büyük bir yük getirilmiş olması da sürdürülebilir değildir. Bu da vergilerin arttıılması ve dolayısıyla üretim maliyetlerinin yükselmesi anlamına gelmektedir. Ayrıca zenginlerin yasal açıklardan yararlanmaları ve iyi mali müşavirler istihdam etmelerinden dolayı gelir vergisi ile kurumlar vergisi sürekli azalma gösterirken stopajalar ile ücretlerden alınan vergilerin artmasıyla sosyal refahı bozucu unsurlar gelişebilecektir. Bu nedenle de üretim, ekonomi ve sosyal refah konularının İslami perspektifle ele alınarak buradaki soruna bir çözüm elde edilip edilmediğinin tartışılması önem arz etmektedir.

Üretim fonksiyonu şu şekilde oluşturulabilir: Fiziki değerler, İşgücü, Sermaye ile teşebbüs ve Allah İhsanı (iman gücü ve ihlas). Refah fonksiyonu parametrelerinden burada üstünde durulan en önemlileri, mikro ve makro düzeyde politika aracı olarak kullanılması mümkün olabilen zekât ile kar payı değişkenleridir. Zekât, üretim sürecine konulmayan belirli düzeydeki servet üzerinden alınan bir gelir transferi olması yönüyle yapısal değişimi de körükler. İsrafın ortadan kaldırılmasıyla zekât gerçek ihtiyaçlar için harcanarak refah etkisi doğurduğu gibi üretim sürecine sokulduğu zaman da büyüme etkisi gösterir. Elde edilebilen fonksiyonlar ise aşağıdaki şekilde ifade edilebilmiştir:

$$
\begin{aligned}
& Y t=Y(P t, K t, L t, F t) \\
& W=W(x, p, C, E, W, I ; M, Z, i, j) \\
& Y=Y p P+Y k K+Y L L+Y f F+Y L L^{\prime} \\
& L^{\prime}=[(d L / d t) .(d f / d t) .(d t / d t) .(d l / d t)]
\end{aligned}
$$

Toplam kar oranı $=(i)(j)[$ pi. $(K(i, j) / K i)]$ 


\section{Kaynaklar}

Akthar, M. (1993). Modelling the economic growth of an İslamic economy. The American Journal of Islamic Social Studies, 10(4), 491-511.

Ansari, M. I. (1994). Islamic perspectives on sustainable development. American Journal of Islamic Social Sciences, 11(3), 394-402.

Aström, Z. H. (2011). Paradigm shift for sustainable development: The contribution of Islamic economics. Journal of Economic and Social Studies, 1(1), 73-84.

Choudhury, M. A. (1991). Micro-macro interface in Islamic economic theory. The Middle East Business and Economic Review, 3(1), 29-38.

Çayıroğlu, Y. (2014). İslâm iktisadının karakteristik özellikleri. İslam Hukuku Araştırmaları Dergisi, 24, 149-183.

Gundolf, K., \& Filser, M. ( 2013). Management research and religion: A citation analysis. Journal of Business Ethics, 112(1), 177-185.

Haneef, M. A., \& Furqani, H. (2009). Contemporary Islamic Economics: The Missing Dimension of Genuine Islamization. Thoughts on Economics, 19(4), 29-48.

Hill, L. E. (1989). Cultural determinism or emergent evolotion: An analysis of the controversy between clarenve ayres and david miller. Journal of Economik Issues, 23(2), 465-471.

Jha, Y. (2013). Examining the meta-principles of modern economics and their implications for Islamic banking and finance. Islamic Sciences, 11(2), 169-184.

Khan, M. F. (2013). Theorizing Islamic economics: Search for a framework for Islamic economic analysis. Islamic Economics 26(1), 209-242.

Koehler, B. (2011). The economist Mohammed Ibn Abdullah (570-632). Economic Affairs, 31(1), 109-111.

Marsuki, M. Z. (2009). Religious agendas towards sustainable development: An Islamic perspective. Malaysian Journal of Science and Technology Studies, 7, 22-38.

Minkenberg, M. (2007). Democracy and religion: Theoretical and empirical observations on the relationship between Christianity, Islam and Liberal Democracy. Journal of Ethnic and Migration Studies, 33(6), 887-909.

Nakvi, N. H. (1985). Ekonomi ve ahlak. İstanbul: İnsan Yayınları.

Nienhaus, V. (2013). Method and substance of Islamic economics: Moving where? Islamic Economics, 26(1), 169-202.

Nursi, B. S. (1956). Lemalar. İstanbul: Envar Neşriyat.

Nursi, B. S. (1960). Mektubat. İstanbul: Envar Neşriyat.

Riis, O. (1989). The Role of religion in legitimating the modern structuration of society. Acta Sociologia, 32(2), 137-153.

Sadeq, A. H. M. (1989). Mobilization of resources for development. The American Journal of Islamic Social Studies, 6(2), 239-256. 
Shittu, A. B. (2014). The Qur'anic worldview: A springboard for cultural reform. Intellectual Discourse, 22(2), 239-242.

Siddiqi, M. (1983). İssues in banking. London: The İslamic Foundation.

Steigerwald, D. (2005). Our new cultural determinizm. Society, January 1, 71-75.

Wilber, C. K. (1974). The 'new' economic history re-examined: R. H. Tawney on the origins of capitalism. American Journal of Economics and Sociology, 33(3), 249-258.

Zaman, A. (2012). Crisis in Islamic economics: Diagnosis and prescriptions. Islamic Economics, 25(1), 143-166. 